\title{
ALWAYS COMING HOME: METIS LEGAL UNDERSTANDINGS OF COMMUNITY AND TERRITORY
}

\section{Kerry Sloan*}

Metis ideas of territory are complex, varied and often not well understood. Metis perspectives on intersections of territory and community are likewise not appreciated by Canadian courts. This is evident in the difficulties of Metis rights claimants in British Columbia, where misconceptions about Metis history and traditional use areas have resulted in courts questioning the existence of historic Metis communities in the province. The leading case on Metis rights in Canada, $\mathrm{R} v$ Powley, requires a claimant to prove there is a historic Metis community in an area where claimed rights are exercised. In BC, courts following Powley in three cases - R v Howse, R v Nunn and R v Willison - have held there are no historic Metis communities in the Kootenays, the south Okanagan, or the Kamloops/Shuswap area. Although these regions comprise only a portion of lands within provincial boundaries, the $B C$ government takes the position there are no Metis communities in the province capable of meeting the Powley test, and thus asserts there can be no Metis Aboriginal rights holders in $B C$.

To challenge this position, and in order to illustrate the multiplicity and richness of Metis legal understandings of territory and community, the author braids family history, narrative, legal analysis and the perspectives of twenty-three Metis people from the southern BC interior who were involved in or affected by the Howse, Nunn and Willison cases. The author suggests that expansive and nuanced Metis understandings of communities and territories cannot be encompassed by the Powley/Willison definition of a Metis community as "... a group of Métis with a distinctive collective identity, living together in the same geographic area and sharing a common way of life". While the court's definition posits history, territory and community as separable, Metis views suggest these concepts are interlinked and mutually constitutive.

The main title of this article is chosen partly in homage to Ursula K Le Guin, whose novel of the same title challenges boundaries concerning "history", "territory" and "community". I realize that some might critique what they see as Le Guin's appropriation of Indigenous stories from California in this novel, perhaps based on her familiarity with her parents' work in cultural anthropology. While I respect this critique, I wonder to what extent the stories Le Guin learned through Alfred Kroeber and Theodora Kracaw Kroeber influenced her questioning of colonialist constructions of territory, of "home".

Thank you to the many people who supported my efforts in writing this article (although any errors or omissions are mine): thanks to my cousin and Elder, Lottie McDougall Kozak, and to my uncle, Todd Sloan, for sharing family stories (with which I may have taken certain liberties); thanks to Jean Barman, John Borrows, Hamar Foster, Christine Goodwin and Benjamin Ralston for providing comments on earlier drafts; thanks also to Elder Maria Campbell and to Karen Drake for some illuminating discussions. While the research and writing of this article was conducted during my PhD studies at the University of Victoria, I would like to acknowledge the support of the University of Saskatchewan College of Law during the revision process. 
Les idées des Métis au sujet du territoire sont complexes, diversifiées et souvent mal comprises. Dans la même veine, les tribunaux canadiens ne comprennent pas les points de vue des Métis sur les liens entre le territoire et la communauté. C'est ce qui ressort des difficultés qu'éprouvent les défenseurs des droits des Métis en Colombie-Britannique, où les perceptions erronées au sujet de l'histoire des Métis et des secteurs qu'ils utilisent à des fins traditionnelles ont incité les tribunaux à douter de l'existence de communautés historiques de Métis dans la province. Selon l'arrêt clé concernant les droits des Métis au Canada, R c Powley, la personne qui revendique des droits est tenue de prouver l'existence d'une communauté historique de Métis dans un secteur où les droits revendiqués sont exercés. Dans la foulée de l'arrêt Powley, les tribunaux de la Colombie-Britannique ont conclu, dans les décisions $\mathrm{R}$ c Howse, R c Nunn et $\mathrm{R}$ c Willison, qu'il n'y a pas des communautés historiques des Métis dans les Kootenays, dans la région d'Okanagan-Sud ou dans celle de Kamloops/Shuswap. Bien que ces régions ne forment qu'une partie des terres situées à l'intérieur des limites provinciales, le gouvernement de la ColombieBritannique soutient qu'il n'existe dans la province aucune communauté de Métis pouvant satisfaire au critère de l'arrêt Powley, de sorte qu'il ne peut y avoir de titulaires de droits ancestraux des Métis.

Pour affirmer le contraire et illustrer la multiplicité et la richesse des perceptions juridiques du territoire et de la communauté chez les Métis, l'auteure entremêle histoire familiale, récits et analyses juridiques, en plus de présenter les points de vue de vingt-trois personnes métisses du sud des terres de la Colombie-Britannique qui ont été touchées d'une façon ou d'une autre par les décisions Howse, Nunn et Willison. L'auteure fait valoir que la définition d'une "communauté de métisse " énoncée dans l'arrêt Powley/Willison, soit "un groupe de Métis ayant une identité collectivité distinctive, vivant ensemble dans la même région et partageant un mode de vie commun », ne peut englober les perceptions ouvertes et nuancées des Métis au sujet des communautés et des territoires. Alors que la définition des tribunaux présente l'histoire, le territoire et la communauté comme des concepts distincts, les points de vue des Métis donnent à penser que ces concepts sont interdépendants et mutuellement constitutifs.

\section{THE GIFT}

The young woman has spent most of the day alone in the bush. She is hungry, and she knows her younger brothers and sisters are too. Her father is riding the range, grazing another man's cattle over the hills and plateaus of the interior ranch lands of British Columbia, the once lush bunchgrass now bleached in the late summer sun. Most years he rides the circuit from Merritt as far as Knutsford, near Kamloops. Her mother has a job in Vancouver, canning salmon. It is up to the young woman, she knows, to feed her siblings today.

She is used to this responsibility, and to these lands and waters - they are part of her, the grasses, the sage, the squirrels, the chickadees and flickers, the rocks with their mica flashing. The familiar smell of ponderosa pine fills her lungs. She knows the rabbits, the mule deer. She doesn't like to have to kill them, 
but they know that. Sometimes, they are willing to give themselves to her, and she is always grateful. If a hunt is successful, she talks to the animal lovingly, respecting its body. She leaves an offering as a renewal of the agreement between their families.

As her practised eyes, ears and nose take in the landscape, soundscape and scentscape, the young woman remembers the story her uncle told her long ago, about how the moose had smoked the peace pipe of the humans, and agreed to sometimes give themselves as food, and also so that the humans could use the moose's hides, bones and sinews. In exchange, humans had promised never to kill more animals than they needed, and - very importantly - had pledged to protect the moose's chosen living places. This was a covenant of mutual respect, and children were taught about it even before they could speak. That's why her mother was so angry when her little brother refused to eat the marrow from his venison bones, and also why her father was upset when her sister took too much meat.

The young woman smiles to herself thinking about the stories of the trickster Little John and how he was always getting into trouble for being wasteful and greedy. Sometimes, he would gorge himself, and leave the rest of his catch roasting over the fire - and then he would fall asleep, and all the meat would get burnt. Usually, the story would end with him getting mad at his bum for failing to wake him up, and with him punishing his bum by sitting in the fire. Her uncle would act this part out, alternately yelling at his rear end and crying, all the while doing what looked like a Red River jig on hot coals. She would laugh, but she knew the message was serious. Killing an animal for nothing was like harming yourself.

As her smile fades, the young woman becomes aware of a rustling in the underbrush. Her attention refocuses and a mature rabbit reveals itself to her. It moves slowly, deliberately, looking her in the eye. She thanks the rabbit, for she and her family will eat tonight.

I first met Elder Lottie McDougall Kozak a few years ago at a Metis ${ }^{1}$ festival in Abbotsford, about seventy kilometres east of Vancouver. I had been hoping to meet her for a while, so that I could ask whether she would participate in my $\mathrm{PhD}$ research project about Metis rights in British Columbia. ${ }^{2} \mathrm{I}$ hoped to interview Metis people from southern $\mathrm{BC}$ about the disappointing application of $R v$ Powley, ${ }^{3}$ the leading Metis rights case, in three cases in the region. Lottie - a life-long hunter and plant gatherer - had been a witness at the trial of Greg Willison, a Metis neighbour of hers who had been charged with hunting out of season and without a licence. She had told the court about Metis history, territorial connections, and culture in the southern BC interior, where she was born and raised. The trial judge listened respectfully

1 I use "Metis" without the accent aigu on the "e" to denote all Metis people, regardless of whether they are of French descent. "Métis" is used where it appears in other works.

2 Karen [Kerry] Sloan, The Community Conundrum: Metis Critical Perspectives on the Application of $\mathrm{R} v$ Powley in Britsh Columbia (PhD dissertation, University of Victoria, 2016) [unpublished]. My dissertation research was conducted as much as possible in line with Metis protocols and approaches to research. Thank you to Metis Elders Lottie McDougall Kozak, Eldon Clairmont, and Samantha Sansregret for your knowledge and guidance. While the field of Indigenous research ethics and methodologies is burgeoning, little has been written explicitly about Metis research. One of the few guides to Metis research ethics was prepared for the Métis Centre at the National Aboriginal Health Organization after consultation with Metis researchers, students and organization members: "Principles of Ethical Métis Research" (2011), Métis Centre <http://www.naho.ca/metiscentre>. Important principles outlined in this guide include reciprocity, respect, safety, inclusivity, recognition of diversity, relevance, and responsibility. Metis thinkers Chris Andersen, Mike Evans, Elmer Ghostkeeper, Judy Iseke, and Tom McCallum have also written about Metis research.

$3 \quad R$ v Powley, [1999] 1 CNLR 153 (Ont Prov Ct), aff'd [2000] OJ No 99 (Ont SC), aff'd [2001] OJ No 607 (Ont CA), aff'd (2003) SCC 43 [Powley]. 
and found that Greg Willison had a Metis right to hunt "in the environs of Falkland," along the historic Fur Brigade Trail running from Kamloops through Falkland and into the southern Okanagan. ${ }^{4}$ Unfortunately, this finding was overturned on appeal. ${ }^{5}$

When I first saw her, Lottie was sitting at a table displaying her bone and wood carvings, her beadwork, and drawings. As I approached, she smiled and laughed a throaty, conspiratorial laugh. It was as if she knew me, knew what I planned to ask her. Happily for me, she agreed to talk with me about the $R v$ Willison case. A few weeks later, as we chatted on the phone, we realized we were cousins. I also discovered she was related by marriage to another cousin of mine in Westwold, a few kilometres west of Falkland along the Fur Brigade Trail. ${ }^{6}$

As I got to know Lottie, I learned that Lottie's great-great-grandfather, Jean-Baptiste ("John") McDougall, who set up the trading post at Kelowna in the 1860s, was the half brother of Duncan McDougall Jr, the father of my great-great-grandmother, Emelie ("Millie") McDougall LaRocque. John was born in 1827 in Fort Garry and came to British Columbia in 1845, working until 1854 for the Hudson's Bay Company as a labourer and bowsman throughout the Columbia District. John's trading post is now reassembled and on display at the Kelowna Museum. His common-law wife, whom he met in Kamloops, was Emelie (or Amelia) Topa, of Secwepemc (Shuswap) and Syilx/Syeelhwh (Okanagan) ancestry. They had ten sons together. After his first wife died, John had two daughters with a Syilx woman known as Julie.

$4 \quad R v$ Willison, [2005] BCJ No 924 (BCPC) [Willison]. The Fur Brigade Trail traversed the land from the northern and central posts to Fort Kamloops/Shuswap, and on through Monte Creek, following the Salmon River through Grande Prairie (Westwold) and Falkland, and down through the Okanagan Valley to posts at Osoyoos and Similkameen/ Keremeos. This trail followed the Columbia River through Fort Okanogan in what is now Washington State to the river's mouth at Fort Vancouver. Another trail following the Willamette River led down into Oregon, creating an eventual Metis settlement in the Willamette Valley, where some of my own relatives travelled, and others eventually settled. For a thorough description of these routes, see James R Gibson, The Lifeline of the Oregon Country: The Fraser-Columbia Fur Brigade System, 1811-47 (Vancouver: UBC Press, 1997).

$5 \quad R v$ Willison (2006) BCSC 985 [Willison; Willison appeal].

6 Both Lottie and research participant Warren Ogden, who grew up in Westwold, assert that there are many Metis families that live along the Brigade Trail from Kamloops to Vernon, including in Westwold and Falkland. Interview with Lottie McDougall Kozak, 15 June 2012, Falkland, BC; interview with Warren Ogden, 19 June 2012, Salmon Arm, BC. However, often written histories do not reflect this reality. For example, see Margaret F Young, Quelle Grande Prairie: History of Grande Prairie, Adelphi and Westwold (Vernon, BC: Wayside Press, 1994). The lack of secondary literature on the history of Metis in British Columbia - despite the availability of primary records - is one of the difficulties faced by Metis rights claimants. Some of the few works that discuss BC Metis history specifically are Jean Barman, "Lost Okanagan: In Search of the First Settler Families" (1996) 60 Okanagan History 8[Barman]; Mike Evans et al, with the Prince George Métis Elders Society (PGMES), A Brief History of the Short Life of the Island Cache (Prince George, BC: PGMES, CCI Press, and Alberta Acadre Network, 2004); Sylvia Van Kirk, "Colonized Lives: The Native Wives and Daughters of Five Founding Families of Victoria" in Mary-Ellen Kelm \& Lorna Townsend, eds, In the Days of Our Grandmothers: A Reader in Aboriginal Women's History in Canada (Toronto: University of Toronto Press, 2006) 170; George Goulet \& Terry Goulet, The Métis in British Columbia: From Fur Trade Outposts to Colony (Vancouver: FabJob, 2008); Jean Barman \& Mike Evans, "Reflections on Being, and Becoming, Métis in British Columbia" (2009) 161 BC Studies 59; Mike Evans, Jean Barman \& Gabrielle Legault, "Métis Networks in British Columbia: Examples from the Central Interior" in Nicole St-Onge, Carolyn Podruchny \& Brenda Macdougall, eds, Contours of a People: Metis Family, Mobility, and History (Norman, OK: University of Oklahoma Press, 2012) 331; Kerry Sloan " Lost Okanagan’ No More: How I Discovered My BC Metis History” (2013) 78 Okanagan History 8. 
While some BC McDougalls identify as Syilx, and others have assimilated into settler society, still others, like Lottie's family, continue to identify as Metis. ${ }^{7}$ As the McDougalls were a prolific bunch, their descendants live all over the province and beyond. Lottie later introduced me to some other Metis McDougalls in Trail, BC, including Elder Goldie McDougall, who also agreed to participate in my dissertation research. Lottie and other Elders and community leaders put me in touch with twenty-one other Metis people in the Thompson/Shuswap, Okanagan, and Kootenay regions who ultimately chose to participate in my project. ${ }^{8}$ Many of the participants were witnesses and litigants in Willison, and in two earlier cases: $R v$ Howse (in the Kootenays), a case about a group subsistence hunt, ${ }^{9}$ and $R v$ Nunn (in the south Okanagan), a possession of wildlife case. ${ }^{10}$

When interviewing Greg Willison, as well as Metis claimant Ron Nunn, who also testified about Metis history in Greg's case, I learned about how Greg's Klyne and my LaRocque ancestors' paths had crossed many times. They met on the eastern slopes of the Rocky Mountains in the early 1800s in connection with the trade route to Kamloops, with some of the LaRocques marrying into the Secwepemc nation. ${ }^{11}$ Michel

7 Oral sources for the genealogical information provided about the McDougalls come from interviews (June-August 2012) with Lottie Kozak, Ron Nunn, and Warren Ogden; with my uncle Todd Sloan of Kamloops; and with my grandmother, Helen Venne Sloan, who has since passed away. Thank you, everyone, for sharing your knowledge. Written sources include those by Metis researcher Gabrielle Legault, Changing in Place: A Generational Study of an Indigenous Family in the Okanagan (MA thesis, University of British Columbia, 2008); by Syilx historian Shirley Louis, We Heard It in the Bushes: The Story of the McDougalls (Calgary: Word Is Out Press, 1996); by the Nicola Valley Archives Association, "The Garcia Story" (1984) 6:4 Nicola Valley Historical Quarterly; various Hudson's Bay Company archival records; various census records; and various scrip affidavits. I apologize for any errors in recounting these family histories; any such errors are mine alone.

8 Thank you to all research participants: Elder Eldon Clairmont (13 June 2012, Salmon Arm); Elder Lottie McDougall Kozak (15 June 2012, Falkland); Lois McNary (17 June 2012, Tappen); Brenda Boyer Percell (18 June 2012, Kamloops); Wayne Bousquet (19 June 2012, Salmon Arm); Warren Ogden (19 June 2012, Salmon Arm); Dean Trumbley (19 June 2012, Falkland); John Sayers (21 June 2012, Salmon Arm); Pat Normand (21 June 2012, Eagle Bay); Mark Carlson (26 July 2012, Trail); Elder Goldie McDougall (27 July 2012, Trail); Bill Gagné (28 July 2012, Vernon); Lori Michon Nicholson (30 July 2012, Enderby): Lenore Willison (31 July 2012, Salmon River); Sandy Milner (31 July 2012, Vernon); Janet Gagné (1 August 2012, Vernon); Elder Ann McBeth (1 August 2012, Lumby); Elder Don McBeth (1 August 2012, Lumby); Beryl Beaupré (3 August 2012, Vernon); Elder Margaret Penner (4 August 2012, Oliver); Ron Nunn (4-5 August 2012, Oliver); Greg Willison (6 May 2013, Salmon River); Dan LaFrance (7 May 2013, Whitley Lake).

$9 \quad R$ v Howse et al, [2000] BCJ No 905 (BCPC), rev'd [2002] BCJ No 379 (BCSC) [Howse], leave to appeal granted, [2003] BCJ No 508 (BCCA) [Howse; Howse appeal].

$10 \quad R v$ Nunn, [2003] BCJ No 3229 (BCPC) [Nunn].

11 See Joachim Fromhold, Alberta History - Jasper National Park: 10,000 Years of Indian History, Part 2, 1750-1850 (Appendix) (London: Lulu, 2011). According to a newspaper interview with LaRocque descendant and Tk'emlups First Nation member Christine Tronson, the LaRocques had land on the east side of the Kamloops reserve. She also states that a widowed daughter-in-law of a Joseph LaRocque married Tk'emlups Chief Louis. According to Ms Tronson, "The LaRocques are like the roots of the reserve." Interview with Christine Tronson, Kamloops This Week (23 August 2012). Thanks to my uncle Todd Sloan for sharing this article. According to Sepwepemc historian Stesmel'ecqen (Ron Ignace), James Teit (1930) recorded Joseph LaRocque's wife as Sukwmelqs, the sister of Chief N'kwala. See Ignace, Our Oral Histories Are Our Iron Posts: Secwepemc Stories and Historical Consciousness (PhD dissertation, Simon Fraser University, 2008) at 227. This LaRocque, Joseph-Félix, was the factor of the Northwest Company post at Kamloops; there were apparently two other Joseph LaRocques who were involved with the fur trade in the Pacific Northwest, one of them at Kamloops. See Sam Pambrun, Frenchtown Historic Foundation, “Who Was Joseph LaRocque?" (18 June 2012). It is difficult to trace the history of the LaRocque family, as LaRocques in Canada may be descended from four different 
Klyne and his wife Suzanne Cardinal dit LaFrance were the replacement postmasters at Rocky Mountain House (afterwards called Jasper House), taking over from my ancestors Jasper Hawes and his Six Nations wife. ${ }^{12}$ Later, the Klyne and LaRocque families came through BC together in 1841 as part of the first Sinclair expedition from Red River to the Oregon Territory. ${ }^{13}$ Greg's great-aunt Jane Klyne settled in BC in the 1840s. When interviewing Dan LaFrance, one of the claimants in Howse, I realized we were also distantly related. Greg Willison and Dan LaFrance are related through Suzanne LaFrance. Howse claimant John Grant Howse, who had been hunting in the Flathead region of the Kootenays when he was charged, is a descendant of Kootenays fur trader Joseph Howse and his Cree wife. ${ }^{14}$ I was intrigued to realize that my ties, as well as the claimants' ties, to the areas of concern in Willison, Nunn, and Howse were richer and older than I had expected.

$* * *$

As a Metis person growing up in British Columbia, I have to admit I didn't know much about the history of the Metis in my home province. I knew a few Metis people at school, even some who were distantly related to me, but at school we only learned about the Metis in Manitoba and Saskatchewan back in the times of Louis Riel. Riel wasn't treated with much sympathy by my history teachers (save one, who was from England), and the history of the Riel "rebellions" was treated similarly to the agitation of the Fenians - that is, anti-colonial activism, whether on behalf of the Irish or the Metis, was misguided and represented nothing more than the shenanigans of a few fringe elements.

French progenitors, two of whom were likely related. A group of Metis LaRocques were associated with the trading post at Rocky Mountain House, traded into Kamloops, and knew the Klyne family. They married into Secwepemc, Cree, and Nakoda families (see Fromhold, ibid).

12 Ian S MacLaren, Culturing Wilderness in Jasper National Park: Studies in Two Centuries of Human History in the Upper Athabasca River Watershed (Edmonton: University of Alberta Press, 2007). Our branch of the family has not preserved the name of Jasper Hawes' wife, and I have not been able to find it in any archival records. The couple has many descendants in the Jasper National Park area, but even the website of the historic Jasper area Metis community does not provide their ancestor's name, describing her only as "Iroquois." See the Mountain Metis website, <http://www.mountainmetis.com/pages/jasper_hawse.html>. Unfortunately, many colonial records failed to document the names of Indigenous women (for example, the Syilx woman partnered with John McDougall was only known to settler records as "Julie"); as well, because of racism and resultant self-silencing, some families did not pass down Metis genealogical information. This self-silencing affected Metis people for many generations and still continues to do so today.

13 "List of Emigrants for the Columbia," Hudson's Bay Company San Francisco Oregon File no 1, F 26/1, fond 2, Hudson's Bay Company Archives. See also Geneva Lent, West of the Mountains: A Biography of James Sinclair, PAM MG 9, A 65-1, 65-2, Provincial Archives of Manitoba. The LaRocques on this journey were my direct ancestors, Pierre and Louis LaRocque. Relatives of Ron Nunn, the Fletts, also participated in this expedition. In addition, Mr Nunn is related to the Duchoquette family, who traded in the south Okanagan. Interview with Ron Nunn, 5 August 2012, Oliver, BC.

14 Although Fromhold, supra note 11, suggests Joseph Howse and Jasper Hawes were the same person, this is not the view of Hawes' descendants (or of Métis Nation of Greater Victoria genealogist Stan Hulme in a post on "MetisGen", <http://archiver.rootsweb.ancestry.com/th/read/METISGEN/2003-06/1056252628>). Jasper Hawes was born in Maryland, moving to Québec as a child with his loyalist parents during the American Revolution. Joseph Howse, the Cree linguist, was born in Cirencester, England, and traded into the Kootenays. See "Howse, Joseph," Dictionary of Canadian Bibliography, <http://www.biographi.ca/en/bio/howse_joseph_8E.html>. See note 12 for a discussion of the issues surrounding the lack of records about Joseph Howse's wife. 
While I chafed at this characterization, and wondered why people talked about the Metis as having only existed in the past, it didn't occur to me then to wonder what Metis people had been doing in BC after Riel or even before. I knew many Metis people, including my own family, had lost ${ }^{15}$ their lands in Manitoba and moved north, south, or west - or all three. Our family, after a few sojourns in many directions, eventually went west. I heard stories about these journeys and about how the extended family kept in touch despite huge distances, but I didn't think closely about the significance of territory to Metis people. I assumed my grandparents' migration from Saskatchewan to BC was the only connection our family had to the province. Much later, as questions of Metis history and law became central to my academic work, I was to discover much of my family's "lost" history ${ }^{16}$ in $\mathrm{BC}$ and to learn about the complexities and contentions of Metis ways of relating to territory.

It was my grandmother who first told me about the Willison case, the most important Metis hunting rights case in BC. Gram told me that the fact that Greg's acquittal had been overturned had something to do with whether there was a historic Metis community near Falkland, where Greg was living, and where he was hunting at the time he was charged. Gram wasn't sure why the historic nature of Falkland (or otherwise) was relevant to his hunting rights, but she was surprised that the appeal judge said there was no historic Metis community in her neighbourhood. My grandparents had lived in Salmon Arm - about thirty kilometres from Falkland - since 1948, so Gram knew the area pretty well. She told me there had been Metis people there for years and that they had a large and thriving community. She wondered how the court could get it so wrong.

I wondered too but wasn't really surprised. I had noticed that most BC residents didn't know Metis people lived in the province. Until recently, even I, as a Metis person from British Columbia, was unaware of the long history of Metis communities in the Lower Mainland where I grew up, on Vancouver Island where I lived, or in the Thompson/Shuswap and Okanagan, where I have many relatives. I began to suspect that one difficulty with the Willison case was the perceived invisibility of BC Metis history. This seeming invisibility means that Metis people in British Columbia may have difficulty meeting the "historic community connection" test for Metis rights, created in 2003 by the Supreme Court of Canada in Powley, a case about moose hunting near Sault Ste Marie, Ontario. ${ }^{17}$ This test means Metis claimants have to prove that the area where they are harvesting is part of a "historic Metis community" and that this community still exists today. They also have to prove that they have many generations of family ties to this community and its territory.

I suspected another difficulty was that most lawyers, judges, and government representatives - and most historians - looked at our history differently from the way we do. For instance, while the BC

15 "Lost" is intended to signify the reality of the many territorial, cultural and political losses faced by Metis people due to colonialism, without describing the Metis as victims or ignoring their agency.

16 Ibid. "Lost' history" is also a reference to the phrase "Lost Okanagan" used by Barman, supra note 6.

17 Powley, supra note 3. Steps 2, 3, 4, and 7 of the ten-part test for Metis rights in Powley comprise the "historic community connection test." Step 2 (paras 21-23) requires identification of the "historic rights-bearing community" where the impugned harvesting (for example, hunting, fishing, trapping, gathering) took place. Step 3 (paras 24-28) requires identification of the "contemporary rights-bearing community" and proof that the modern community is a continuation of the historic community. Step 4 (paras 29-35) requires proof of the claimant's membership in the subject community. This includes proving (1) self-identification as a member of the community; (2) ancestral connection to the community; and (3) acceptance by the community. Step 7 (para 45) requires establishment of continuity between the historic community practice and the contemporary right. 
government's position is that there are no historic Metis communities in British Columbia (with the possible exception of in the Peace River country), ${ }^{18}$ most of the people who participated in my dissertation research told me that there are many historic Metis communities in the province, especially near all of the old fur trading posts. Other participants questioned the courts' notions of history as being influenced by European thinking, ${ }^{19}$ as Powley requires that Metis people must prove the impugned practice - say, moose hunting - was carried on by their community in its territory from the time before "European control." ${ }^{20}$ In Willison, this date has been held to be 1846, the date of the Oregon Treaty, which established the boundary between the United States and British-claimed territory. While this date was important to some Metis people, as the treaty negatively affected the Pacific Northwest fur trade, to require that 1846 be the year by which people's rights had to crystallize seemed arbitrary to participants. In their view, history is continually being created, and culture is continually being revitalized.

As I thought about how the Powley case had been applied in Willison, I returned to my grandmother's question about why it should matter whether historic communities existed where people were harvesting. Why did the Powley court think this was important? What did the court mean by "historic"? What did it mean by "community"? ${ }^{21}$ And what were the assumptions the court was making about Metis territories?

18 BC's Métis Policy Framework (2011) states: "[T]he Province does not recognize a legal obligation to consult with Métis people as the Province is of the view that no Métis community is capable of successfully asserting site specific Section 35 rights in B.C." See BC Métis Federation <http://www.bcmetis.com/wp-content/uploads/M\%C3\%A9tis-PolicyFramework-Final-October-2011-1.pdf>. However, British Columbia has consulted with the Metis in the northwestern part of the province on the BC Hydro Site C Dam proposal, where a land use study triggered a "medium" level of consultation.

19 Interview with Elder Eldon Clairmont, 13 June 2012, Salmon Arm, BC; interview with Elder Goldie McDougall, 27 July 2012, Trail, BC.

20 This comes from Part 5 of the Powley test requiring identification of the relevant time frame (paras 36-40). This test was adapted from the pre-European-contact test outlined in $R v$ Van der Peet, [1996] 2 SCR 507 [Van der Peet] for determining which practices, customs, and traditions were "integral to the distinctive culture" of Aboriginal rights claimants. For an "Indian" proving an Aboriginal right, the court in Van der Peet held that the impugned practice, tradition, or custom must be shown to have been integral to the community prior to "contact" with Europeans. See $R v$ Sparrow, [1990] 1 SCR 1075; Van der Peet, ibid at para 61. The test was modified in Adams, wherein the court held that "contact" meant "effective control." See $R v$ Adams, [1996] 3 SCR 101. For a Metis proving an Aboriginal right, the court in Powley modified the time period to be "post-contact but pre-control," taking into account that Metis societies necessarily arose after contact. Powley, supra note 3 at para 37.

21 One of the central critiques of almost all of the research participants about the application of Powley was that Metis understandings of community were not taken into account by the courts. My dissertation deals with this in detail. Other writers who have discussed "community" in light of Powley include Andrea Horton \& Christine Mohr, "R. v. Powley: Dodging Van der Peet to Recognize Métis Rights" (2005) 30 Queen's LJ 72; Brent Olthuis, “The Constitution's Peoples: Approaching Community in the Context of Section 35 of the Constitution Act, 1982" (2009) 54 McGill LJ 1; Chris Andersen, "Settling for Community? Juridical Visions of Historical Metis Collectivity in and after R. v. Powley" in StOnge, Podruchny \& Macdougall, supra note 6, 392; Sébastien Grammond \& Lynne Proulx, "Finding Metis Communities" (2012) 32:1 Canadian Journal of Native Studies 33; Jean Teillet, Métis Law in Canada (Toronto: Pape Salter Teillet, 2013) [Teillet], Pape Salter Teillet <http://www.pstlaw.ca/resources/Metis-Law-in-Canada-2013.pdf>; Chris Andersen, "Métis”: Race, Recognition, and the Struggle for Indigenous Peoplehood (Vancouver: UBC Press, 2014); Sébastien Grammond, Isabelle Lantagne \& Natacha Gagné, "Non-Status Indigenous Groups in Canadian Courts: Practical and Legal Difficulties in Seeking Recognition" in Patrick Macklem \& Douglas Sanderson, eds, From Recognition to Reconciliation: Essays on the Constitutional Entrenchment of Aboriginal and Treaty Rights (Toronto: University of Toronto Press, 2016) 259. Arthur J Ray, the Powleys' expert witness, talks about "Defining Métis Communities and Customs" in the aftermath of Powley in Chapter 6 of his book, Telling it to the Judge: Taking Native 
I already mentioned the two other harvesting rights cases in $\mathrm{BC}$ that followed Powley: Howse and Nunn. These cases followed the Powley Ontario Court of Appeal decision, as the case had not yet gone to the Supreme Court of Canada. As in the Willison appeal, the Metis rights claimants in Howse and Nunn lost in part because they "failed" the historic community connection test. The courts simply decided that there had never been historic Metis communities in these areas. ${ }^{22}$

\section{A COMMUNITY DIALOGUE}

A Metis legal colleague told me lately that he agreed with me that there were many ways of being Metis. But he argued that there needed to be some definition of "community" in the law, otherwise "all sorts of people" could start illegitimately claiming Metis rights. When I asked him what he meant, he said that he didn't think urban, assimilated Metis should have constitutionally protected harvesting rights.

Rather taken aback, I asked him whether he didn't think that the modern reconstitution of Metis communities was valid. He replied "Yes, but only in the political sense. Not in the cultural sense." Efforts to preserve "living" traditional culture were valid, he asserted, but "true community" could not be recreated by urban people who merely got together once a month and dressed up in sashes and beaded jackets.

As an (arguably) assimilated and (mostly) urban Metis, I asked my colleague if he meant the inherent complexity of Metis (my) history should mean that some Metis (me) would not have constitutionally protected Aboriginal harvesting rights? Perhaps this is as it should be - aren't such rights connected to territory? What is Metis territory? That was another tricky question. But I left that for a moment.

I asked another question, more to myself than to him, "Do First Nations or Inuit people lose their Aboriginal harvesting rights if they live in cities? Or in other communities?" Then I addressed him directly. "Are you a hunter?" "Yes." "Well," I said, "Don't you live in a city?" He thought for a moment. Musing, he said, "Well, I didn't always, and I still go back to my home community in Saskatchewan to hunt." I said, "What is your real home? Here or there?" He thought again, "Both, I guess. What about you? Where's your home community?" "Well," I said, "I grew up in Coquitlam, BC; I've lived in Nova

History to Court (Montreal and Kingston: McGill-Queen's University Press, 2011). He elaborates on this in his article, "The Métis in Court: Problems of Discrimination, Identity, and Community," in Arthur J Ray, ed, Aboriginal Rights Claims and the Making and Remaking of History (Montreal and Kingston: McGill-Queen's University Press, 2016 ) ch 7.

22 Willison appeal, supra note 5 at para 44; Nunn, supra note 10 at para 33; Howse appeal, supra note 9 at para 34. One reason given by the judges in the final rulings on all these cases was that the evidence presented did not support a finding that "historic" Metis communities existed in the subject areas. Given the lack of secondary research on Metis history in $\mathrm{BC}$, it is difficult and expensive for claimants to gather historical evidence. Sometimes, evidence is simply not available. For instance, one of the issues in the Willison trial was documentation of the number of Metis people living in and around Fort Kamloops. Even though expert historical evidence was tendered suggesting a Metis presence in the area before "European control," the appeal judge held that this presence was insufficient to support the existence of a "community." Two weeks after the case wrapped up, Oblate records were unsealed showing the presence of more than seventy Metis individuals at Kamloops at the relevant time, many of whom would have had families. According to many participants, if this information had been available at the time of trial, Greg Willison's case would have been appeal proof. Unfortunately, due to a lack of funds and other issues, a re-trial was not pursued. Evidentiary issues in Willison, including participants' concerns about the treatment of oral history evidence, are detailed in my dissertation. Note that the Oblate Fathers still require researchers to obtain written permission in order to access their records held at the Archives of British Columbia. This requirement will remain in place until 2030. 
Scotia, Ontario, Alberta, overseas, and most recently in Victoria - although I'm now working for a while in Saskatchewan. But I've spent a month or two almost every year in the country in the southern interior of $B C$, where most of my relatives live. I guess I feel at home there and on the coast, but my parents and grandparents are from the prairies and I've lived there too ... all of those places are home in a way." "Are you a hunter?" he asked. "No, although my grandpa taught me how to shoot. But my grandpa and uncles hunted, and my grandpa trapped. Mostly, I harvest plants and mushrooms for food and medicine, and I've occasionally gone fishing. Once, when I lived in Vancouver, I went fishing at the mouth of the Capilano River without a licence. I was young and innocent, and didn't know a licence was required just to fish for food (I also didn't know I should ask First Nations for permission). I was hoping my innocence would save me when the fisheries guys tried a few times to get close to our boat to see our licences. Luckily, every time they approached, a big wave came, and they gave up." I smiled at the memory. "Of course, this was before Powley, even before I became a lawyer. But I wouldn't want you to think that I, as an urban Metis with no rights, would deliberately do anything an officer of the court wouldn't do." I winked, and he laughed. "Well, it's your paper," he said, "So I'll give you the last word."

In the beginning of my dissertation project, I wasn't thinking too much about territory; my focus was more on historical continuity and community construction. However, when reading both written materials and listening to participants' interviews, I began to see how the Metis networks that existed across the prairies and elsewhere in Canada and the United States were interconnected with networks in BC. Family, work, and social connections have been forming in what is now referred to as British Columbia for over 200 years. ${ }^{23}$ These connections are inseparable from territory in many respects. Despite the vastness of the geography in which Metis people have lived and worked, there remain territorial hubs, connected by web-like networks of kinship and other relationships ${ }^{24}$ - and these networks are continually being renewed. In BC, territorial hubs include former fur trading posts such as Prince George, Quesnel, Fort St John, Kamloops, Kelowna, and Fort Langley, to name a few. ${ }^{25}$

Considerations of territory forced themselves on my notice because of the definition in Powley of a Metis community. According to the Supreme Court of Canada, "[a] Métis community can be defined as a group of Métis with a distinctive collective identity, living together in the same geographic area and sharing a common way of life." 26 The Willison appeal judge held that the trial judge

expanded the definition of community found in Powley to include a geographically wide, loosely affiliated group of people of mixed ancestry rather than a group with a distinctive,

23 On this point, see Barman \& Evans, supra note 6; Barman and Evans, along with Metis historian Gabrielle Legault, elaborate on this topic in "Métis Networks in British Columbia: Examples from the Central Interior" in St-Onge, Podruchny \& Macdougall, supra note 6.

24 On Metis understandings of kinship and territory as being web-like, see the discussion of wahkootowin in Brenda Macdougall, One of the Family: Metis Culture in Nineteenth-Century Northwestern Saskatchewan (Vancouver: UBC Press, 2010).

25 I am not using the word "territory" to denote Metis title, but rather to describe areas that Metis people lived in over time and in which they continue to exercise rights. Issues arising from Metis harvesting in the traditional territories of other Indigenous nations are discussed below.

26 Powley, supra note 3 at para 12. 
collective identity, living together in the same geographic area and sharing a common way of life. I respectfully find this to be an error. ${ }^{27}$

What is difficult about this reasoning is that these distinctions are fuzzy if one looks at Metis communities and history from a Metis perspective - and this was one of the fundamental critiques by the research participants. For instance, participants told me that Metis communities and culture are distinctive, but their ancestry and sense of collective identity are multiplicitous and complex; they told me that they might live "together" in a very large geographic area and that they might share common lifeways (such as mobility) in forms not recognizable by others. While they did not think their affiliations were "loose," they acknowledged others might have different understandings about affiliation. For research participants, community contact did not have to be frequent. Participants also stated that they have "outside" affiliations, such as with their First Nations relatives. Generally, people described the courts' view of Metis communities as not being expansive or nuanced enough. Some participants questioned whether the term "community" really described how Metis people organize themselves ${ }^{28}$

The requirement that a Metis community be based "in the same geographic area" follows the determination in Powley (and in other Aboriginal rights cases) that Aboriginal rights are "site specific." How specific a site has to be is a matter of debate. In Powley, it was held that the Metis community in Sault Ste Marie was not limited to the town site itself but included outlying areas historically (although sometimes infrequently) inhabited by Metis people. Thus, in Willison, the trial judge reasoned that the requirement that rights be "site specific" did not mean that Greg Willison could only hunt in a limited area surrounding the town site of Falkland, which is small and, in any event, does not technically include his residence. The trial judge held that Greg's rights were exercisable "in the environs of Falkland," which extended along the path of the historic Fur Brigade Trail from Kamloops through Westwold, Falkland, Vernon, through the Okanagan, and down into Washington State.

While this finding was not overturned, the appeal judge did not seem to be as concerned about the location or extent of the territory as he was about whether there was a historic Metis community in this fairly large "environs." Nevertheless, part of the reason the appeal judge decided that such a community did not exist was that evidence was provided by a defence expert witness that Metis people ranged over the entire Pacific Northwest with the fur trade, beginning in the early 1800s, and may or may not have settled permanently in what became known in 1858 as British Columbia. ${ }^{29}$ However, in his testimony, this witness, Dr Michael Angel, commented that the reason he chose to describe the Metis operating in such a large geographic area:

27 Willison appeal, supra note 5 at para 48.

28 Rights claimant Dan LaFrance questioned the boundaries between "community" and "nation," reminding me that these were imposed terms. Interview with Dan LaFrance, 7 May 2013, Whitley Lake, BC. Many participants described communities as more or less localized subsets of the Metis nation, although Greg Willison, for instance, suggested that the nation as a whole could also be characterized as a community. Interview with Greg Willison, 6 May 2013, Salmon River, BC. Arguably, the focus by courts on "community" rather than on "nation" (as well as de-emphasizing Metis nationhood) is at odds with jurisprudence on First Nations rights. Tsilhqot' in Nation v British Columbia, [2014] 2 SCR 257, says that the proper rights holder is the wider nation, not individual bands.

29 British Columbia amalgamated with the colony of Vancouver Island in 1866, creating the current boundaries of BC. 
is that you can't simply take a Metis community in much the same sense that you might want to take a white community and say that people have come in here and settled and this is their community because of the very fact that the fur trade was based on the communication system, that it was in constant motion every year and people just did not live in one little community. ${ }^{30}$

While this reasoning did not persuade the appeal judge, it did reflect the understanding of many of the research participants, who viewed themselves as highly mobile and viewed their cultural practices, including hunting, as having always been portable. The mobility of the Metis meant that Metis people harvested in many parts of North America, particularly in northwestern North America. ${ }^{31}$

I was told by most research participants that Metis people in $\mathrm{BC}$ hunted all over the province and continue to do so today. For instance, I learned that some Metis from the Shuswap and Okanagan areas hunt in the Kootenays, as well as near Chetwynd and even as far north as the Yukon border. ${ }^{32}$ Other participants told me Metis people from other provinces come to $\mathrm{BC}$ to hunt, especially in the Rocky Mountains. ${ }^{33}$ It so happened that Greg Willison had been hunting close to where he lived when he was charged. Ron Nunn was also in the general area of his residence in Oliver when he was charged, and the hunters in Howse were living in the Kootenays at the time, although claimant Dan LaFrance only lived in the area for a short time. (He moved many times, living all over BC as well as in Manitoba.)

However, it could easily happen that a Metis person might be charged in relation to hunting in an area that would not be in that person's "community." For instance, what if Greg had been in Kelly Lake, a historic Metis community in northeastern BC, at the time he was charged, but was still living in Falkland? Even though his local community was in Falkland, he would have been in the position of having to prove that there was a historic Metis community in Kelly Lake and that he had an ancestral connection to such a community. Although it is probable, based on the complexity of Metis history and migrations, that an individual might have family ties and other connections to more than one local community, the Powley requirements leave many questions unanswered. What if someone were charged with harvesting offences in more than one place? Would that person have to prove a historical/modern community/ancestral

30 Willison, supra note 4, cross-examination of Michael Angel on voir dire, trial transcript, 16 June 2004, at 30, lines $22-$ 29.

31 This mobility and portability of rights does not equate with the untrammelled exercise of those rights in the territories of other nations. This issue is dealt with later in this article and is a matter for (hopefully) nation-to-nation dialogue, with or without crown participation.

"Metis" is a fetishized term, and a discussion of who is and is not Metis is a large and complex topic that is beyond the scope of this article. For the purposes of my research, I interviewed people who self-identified as Metis and were recommended to me by Elders and community leaders as being part of the wider Metis community/nation, regardless of Metis political affiliation. Metis migration to, and ethnogenesis in, British Columbia is discussed in my dissertation; by Barman \& Evans, supra note 6; and by Barman, Evans \& Legault, supra note 6. My own view is that there may be more than one distinct Metis nation in North America but that large numbers of Metis people in BC are part of the "Metis of the Northwest." In his paper "By Birth, Adoption or Other Means: Being, Becoming, and Belonging as Métis in British Columbia" (nd) [unpublished], Bruce Leslie Poitras suggests an expansive definition of "Metis" in the BC context, but one that is rooted in Metis political agency and community.

32 Interview with Elder Lottie McDougall Kozak, 15 June 2012, Falkland, BC.

33 Interview with Greg Willison, 6 May 2013, Salmon River, BC; interview with Kootenay region Hunt Captain Mark Carlson, 26 July 2012, Trail, BC. 
connection to more than one local community? This possibility was raised in Willison, with the appeal judge acknowledging that Greg might have hunting rights in Lebret, Saskatchewan, where he was born and lived for one year before coming to BC. This possibility also further illustrates the weakness of Powley (and its parent case, $R v$ Van der $P e e t^{34}$ ), which considers that harvesting is a site-specific right. I am not clear this can or should apply to Metis people in all circumstances, given their historic and current tendency to be highly mobile and to have a variety of territorial connections.

Nevertheless, the mobility of the Metis does not mean that Metis harvesting lacks territorial connections, or has only amorphous territorial connections; rather, it suggests that Metis connections to territory are varied and may not be widely understood by others. In some areas, Metis relationships to territory may be more in the nature of cultural use; in others, they may be more akin to shared occupation. ${ }^{35}$ Some Metis have claimed title to areas of northwestern Saskatchewan, ${ }^{36}$ and others have joint claims with the Dene in the North. ${ }^{37}$ In areas where Cree, Anishinaabeg, or Dene territories are shared with Metis, who are their relatives, there may be fewer inter-nation conflicts about territory and use rights. ${ }^{38} \mathrm{In} \mathrm{BC}$, where there are many Indigenous nations, some with territorial overlaps - and where there are few treaties with the Canadian state - claims to Metis use and occupation may be more contentious. Depending on whether inter-societal relationships, including legal relationships, have developed, Metis incursions into the territories of other nations may be considered illegal. Given the profusion and complex nature of Indigenous territories in $\mathrm{BC}$ and across Canada, it will be challenging for Metis to establish the multiplicity of respectful relationships with other nations prescribed by traditional Metis laws and values. Nevertheless, I believe we must try, and must include First Nations in any attempts to negotiate harvesting rights with state-based governments. ${ }^{39}$

\section{CREATING COMMUNITY: METIS AND FIRST NATIONS TERRITORIES}

In a group discussion with Indigenous leaders, a First Nations man stated that Metis were basically a "prairie thing" and were therefore not important in British Columbia. When I politely asserted that Metis people had been in BC for at least 200 years, he looked angry but said nothing - at the time. Later, he

$34 \quad$ Van der Peet, supra note 20.

35 See Teillet, supra note 21 at 3-6-3-7.

36 Morin v Canada and Saskatchewan (1994) SKQB 619. This action has been stayed. A Metis title claim was also made in the Northwest Territories in Paul and North Slave Métis Alliance v Canada, NWT and Dogrib Treaty 11 Tribal Council (2002) FCT 615. Manitoba Métis Federation v Canada, [2013] 1 SCR 623, was not a title case, but sought a declaration that the Metis were unjustly deprived of lands protected under the Manitoba Act, 1870.

37 For example, see the Sahtu Dene and Métis Comprehensive Land Claim Agreement (1993). See Teillet, supra note 21 at 3-14-3-16, regarding other northern agreements involving Metis.

38 On this point, see Cree scholar Robert Alexander Innes, Elder Brother and the Law of the People: Contemporary Kinship and Cowessess First Nation (Winnipeg: University of Manitoba Press, 2013) at 80-89. Innes states that, while conflict about harvesting existed between Metis and Cree, Saulteaux and Assiniboine peoples, it was not resolved by violence because of the kinship obligations that existed amongst these culturally interconnected groups. I am grateful to Metis scholar Karen Drake for a similar observation about Metis and Anishinaabeg kinship ties and intersocietal law in the Thunder Bay area: personal communication with Karen Drake, 30 November 2016.

39 This possibility has already been anticipated to some extent by the drafters of the Métis Nation of British Columbia Natural Resource Act, 2010 (revised), which in section 7.2 provides a mechanism for entering into wildlife management agreements with First Nations. 
unleashed an online diatribe about how Metis people thought it was a big deal that they had been in British Columbia for a few generations, when his nation had been here since time immemorial. I felt terrible, as by making my assertion I hadn't meant to disrespect other people - or peoples. It turned out this man's frustration was about Metis hunting in his nation's territory and not asking permission. I was saddened to hear about this, as in the past we usually did ask permission.

I didn't respond to this man immediately, but thought often of what I might say to him. I imagined myself telling him about Metis territories, about their complexities.

I wanted to tell him that, in the beginning, as Metis (or proto-Metis), we obtained use, occupation and passage rights through First Nations territories through diplomacy, blended legal systems, marriage, adoption and, occasionally, warfare. ${ }^{40}$ We gained territories through relationships with our First Nations relatives and also enjoyed communal property holding with them. ${ }^{41}$ As with our French Canadian ancestors, some Metis families held property distributed along the Red and other rivers in the manner of the Québec seigneurial system, in which each landholder had a small piece of river frontage, the plots trailing out from the riverbank in long strips. This practice was also carried on in the Pacific Northwest. ${ }^{42}$ Many Metis used these (and other) more permanent settlements as "hubs," as places to return to, since much of the employment of the Metis involved long months of travel. For instance, the journey from Montréal to Red River was one of over 2,300 kilometres and took one-and-a-half to two months. As Metis people, we kept our family connections over these long distances and absences. Thus, even one family might have had more than one type of territorial connection. ${ }^{43}$

I wanted to tell him that, on the prairies, we negotiated shared harvesting rights with various nations, as in the Metis treaties with the Dakota and Chippewa in 1859 and 1861. In other instances, we were allowed to establish settlements in First Nations territories. Over time, such settlements came to be seen as distinctively Metis. ${ }^{44}$ Examples include Île à la Crosse, St Laurent, Lac Ste Anne, and Red River. Some

40 For example, see Richard White, The Middle Ground: Indians, Empires, and Republics in the Great Lakes Region, 16501815 (Cambridge: Cambridge University Press, 1991); Susan Sleeper-Smith, Indian Women and French Men:

Rethinking Cultural Encounter in the Western Great Lakes (Amherst, MA: University of Massachusetts Press, 2001). Regarding passage rights of Metis (or proto-Metis) through the Toronto area, see Jesse Thistle, "Listening to History: Correcting the Toronto Metis Land Acknowledgement," History Matters (6 December 2016), Active History <http://activehistory.ca/2016/12/listening-to-history-correcting-the-toronto-metis-land-acknowledgement/>. This article highlights some of the difficulties in understanding Metis historical and territorial connections.

41 Powley, supra note 3. Arthur J Ray, expert witness report (for the defence). See also Innes, supra note 38.

42 Bruce McIntyre Watson, Lives Lived West of the Divide: A Biographical Dictionary of Fur Traders Working West of the Rockies, 1793-1853, vol 1 (Kelowna: Centre for Social, Spatial and Economic Justice, University of British Columbia, 2010).

43 For an example of a complex Metis view of connection to territory, see Emma LaRocque, When the Other Is Me: Native Resistance Discourse, 1850-1990 (Winnipeg: University of Manitoba Press, 2010) at 136-137.

44 Innes, supra note 38, states at 83 that in the negotiations for Treaties 4 and 6, First Nations leaders requested that Metis be included in treaty, signifying acknowledgment of shared territory and rights. First Nations leaders also asked for Metis to be included in the Robinson-Superior Treaty of 1850: see the report of treaty negotiator William B Robinson to Colonel Robert Bruce, Superintendent-General of Indian Affairs, 24 September 1850, reproduced in Alexander Morris, The Treaties of Canada with the Indians of Manitoba and the North-West Territories, Including the Negotiations on Which They Were Based, and Other Information Relating Thereto (Toronto: Belfords Clarke, 1880) at 17-21. See also Morris, ibid, at 16. Metis people were included in various of the numbered treaties, and there was a specific Metis adhesion to Treaty 3 . 
of the Metis settlements in the far North existed before the Red River period, ${ }^{45}$ and there are now many people in the North (and elsewhere) who identify as both First Nations and Metis.

I wanted to tell him that, many times, Metis and First Nations people lived and fought side by side, as when we tried to protect our territories along the Red River against encroaching Canadian settlement, leading to the first Riel Resistance in 1869. I wanted to tell him that, despite the efforts of the Metis in negotiating with Canada for our land rights in what became the province of Manitoba in $1870,{ }^{46}$ we were dispossessed of our lands there through the "land scrip" process, in which we were meant to be guaranteed a certain portion of our traditional lands or to be able to trade in our lands for money. ${ }^{47}$ While this was supposed to ensure we retained access to our territories, in part in exchange for the entry of Manitoba into Canadian confederation, in practice, speculation and fraud was rife, and many people were deprived of their lands. ${ }^{48}$ Because of the scrip fiasco, many Metis went west, creating settlements in Saskatchewan, Alberta, BC, and the North. Some of these territories, which were more or less continually occupied, came to be seen as traditional.

I wanted to tell him that when the integrity of the Metis territories in Saskatchewan was violated by west-reaching Canadian settlement, this led to the second Riel Resistance in 1885, and the dispersal of more Metis people across Canada and into the United States. I wanted to tell him that many of us were forced to live on railway rights-of-way and on road allowances, because we had no land, and couldn't afford to live anywhere else.

45 See Richard Slobodin, Métis of the Mackenzie District (Ottawa: Canadian Research Centre for Anthropology, St Paul University, 1966); Nicole St-Onge, "Early Forefathers of the Athabasca Métis: Long-Term North West Company Employees" in Ute Lischke \& David T McNab, eds, The Long Journey of a Forgotten People: Métis Identities and Family Histories (Waterloo, ON: Wilfrid Laurier University Press, 2007) 109.

46 Darren O'Toole, "Métis Claims to 'Indian' Title in Manitoba" (2008) 28:2 Canadian Journal of Native Studies 241. Some scholars have critiqued the First Nations-Metis alliances in Manitoba and Saskatchewan, asserting that Riel used First Nations people for his own political aims. For instance, see Blair Stonechild \& Bill Waiser, Loyal till Death: Indians and the Northwest Rebellion (Calgary: Fifth House, 1997). I discuss this problem in another work: Kerry Sloan, “"A New German-Indian World in the North-West': A Métis Deconstruction of the Rhetoric of Immigration in Louis Riel's Trial Speeches" in Hans V Hansen, ed, Riel's Defence: Perspectives on His Speeches (Montreal and Kingston: McGill-Queen's University Press, 2014) 166. Regarding First Nations participation in the 1885 Resistance, Innes, supra note 38, states at 87-88 that Chief One Arrow joined Riel's cause willingly. On this point, Innes cites Richard John, former chief of One Arrow First Nation.

47 For a description of how scrip worked, see Frank Tough \& Erin McGregor, "“The Rights to the Land May Be Transferred': Archival Records as Colonial Text - A Narrative of Métis Scrip" in Paul W dePasquale, ed, Natives and Settlers, Now and Then: Historical Issues and Current Perspectives on Treaties and Land Claims in Canada (Edmonton: University of Alberta, 2007) 33.

48 See, for example, Frank Tough, "As Their Natural Resources Fail”": Native Peoples and the Economic History of Northern Manitoba, 1870-1930 (Vancouver: UBC Press, 1996), ch 6. The implications of this for the relationship between the Metis and the federal crown went unaddressed until the decison in Manitoba Métis Federation, supra note 36, in which the court declared the crown had failed to implement the land grant system in section 31 of the Manitoba Act, 1870 in accordance with the "honour of the crown." Some Metis did willingly sell their own lands, moving elsewhere to escape encroaching settlement and government control, but even such freely chosen transactions were often exploitative, with Metis sellers getting far below market prices. 
I wanted to tell him that because of the efforts of five Metis activists in the 1930s, eight traditional Metis settlements in Alberta became protected under provincial legislation. ${ }^{49}$ Today, these settlements are governed under the Metis Settlements Act ${ }^{50}$ and have their own tribunal, the Metis Settlements Appeal Tribunal. Alberta is the only province with such legislation.

I wanted to tell him that in BC Metis people have been explorers, fur traders, trappers, pack train drivers, cowboys, farmers, hay traders, fishers, fallers, truck drivers, day traders. We have many networks and many relations across the province and beyond. We are intermarried into many First Nations, and also into many other nations, but we are still Metis. We still live in and around the hubs of former fur trading posts, and along the Fur Brigade Trail "in the environs of Falkland."

I wanted to tell him that, while many Metis people today live in traditional settlement areas, many of us do not. Some of us may be urban, some may be rural. The modern Metis nation is thus made up of many communities, some of which are physically disparate, some of which are separated from their traditional land bases, and some of which are arguably not attached to particular lands.

I wanted to tell him that, despite these varieties and complexities, there were and are Metis territories, and established Metis use rights, and that - as history is continually being created - I hoped that Metis and First Nations people could have a dialogue about territories and about rights.

But would dialogue be enough? What might it entail? How could we listen to each other better? Remembering the First Nations man's anger, seeing his face-and his Facebook page - in my mind's eye, I knew that dialogue alone would not solve the problem of Metis hunting in other nations' territories without asking permission; it would not prevent First Nations leaders from refusing permissions out of fear-fear of Metis intentions, fear of political criticism within their own nations. Talking and learning more about each other would be necessary, but people would also need to create relationships, trust, and community. Although I was nervous, I decided to talk to the First Nations man during a subsequent meeting, and, to my surprise, he seemed curious to know more about Metis people. He was surprised in turn when I told him that one of my cousins had married into his nation. It was a small beginning, but one that I hoped we could build on.

During the appeal in Willison, the Okanagan Nation Alliance ${ }^{51}$ applied to intervene, concerned that the court was going to make a determination about Metis rights in their territory. Although the intervention application was denied, tensions between the Metis and the Okanagan were high. According to some participants in my research project, it was hard for them to sit in the courtroom, as they had friends and relations on both sides. ${ }^{52}$ Tension between the Okanagan and the Secwepemc (Shuswap) was also high, because Falkland, where Greg Willison had been hunting, is in a territorial overlap area in dispute between the two nations.

49 Nicole C O’Byrne, “'No Other Weapon Except Organization': The Métis Association of Alberta and the 1938 Metis Population Betterment Act” (2013) 24:2 Journal of the Canadian Historical Association/Revue de la Société historique du Canada 311.

50 Metis Settlements Act, SA 1990, c M-14.3. See Catherine Bell, Alberta's Métis Settlements Legislation: An Overview of Ownership and Management of Settlement Lands (Regina: Canadian Plains Research Center, 1994).

51 The Okanagan Nation Alliance (ONA) represents eight member communities in Syilx traditional territory in British Columbia and Washington State. See ONA <http://www.syilx.org/who-we-are/organization-information/>.

52 Interview with Janet Gagné, 1 August 2012, Vernon, BC; interview with Ron Nunn, 5 August 2012, Oliver, BC. 
Many of the research participants stressed to me that they were not trying to claim or encroach on the territory of other nations and that they wanted people to know that Metis expressions of territory in BC were not meant to be exclusive but were more in the nature of use rights and occupancy, due to the mobility of the Metis and the portability of their rights. ${ }^{53}$ According to Ron Nunn, who sought permission (unsuccessfully) to hunt in Syilx territory,

[o]ne thing about Metis people - we always bring our culture with us because our culture is portable. It's not established to a land base, since we never had a land base like Indians did [in British Columbia]. We used the land, but this was not viewed as "this was our land," you know, since time immemorial ... Not that we didn't have a tie to the land, culturally and spiritually, but we had more of a mobile history, a mobile culture. The mobility factor is that Metis moved where the best opportunities were for them. They lived along the road allowances because they were not wanted any other place. ${ }^{54}$

Other participants informed me that the Metis and Secwepemc organize a periodic joint hunt in Secwepemc territory. ${ }^{55}$ Dan LaFrance told me he received permission from a local First Nation to be on his trapline near Vanderhoof. ${ }^{56}$ Still, sometimes I worry Metis and First Nations people don't talk to each other enough about these issues. Mobility is a facet of many Indigenous cultures, not just of Metis cultures $;{ }^{57}$ there is a tension between rootedness and mobility that is only now starting to be explored. ${ }^{58}$ Maybe talking about this is a way to begin.

53 Greg Willison, for instance, describes the Metis as having a "homeland" - lands where Metis live and harvest - that encompasses a large portion of northwestern North America. He doesn't think Metis have traditional territories (except in a few instances) in the way that First Nations or Inuit people do. Interview with Greg Willison, 6 May 2013, Salmon River, BC. On Indigenous governance in cases of mobility, territorial overlaps and rights of Indigenous minority groups within Indigenous traditional territories, see Ghislain Otis, "Territoriality, Personality, and the Promotion of Aboriginal Legal Traditions in Canada" in Law Commission of Canada, ed, Indigenous Legal Traditions (Vancouver: UBC Press, 2007) 136.

54 Interview with Ron Nunn, 4 August 2012, Oliver, BC. Mr Nunn's case involved possession of the carcass of a deer shot by a non-Aboriginal hunter.

55 Interview with Wayne Bousquet, 19 June 2012, Salmon Arm, BC; interview with Dean Trumbley, 19 June 2012, Falkland, BC.

56 Interview with Dan LaFrance, 7 May 2013, Whitley Lake, BC. This, of course, raises issues about who might be the correct people to ask - Chief and Council, traditional leadership, Elders, or others - and it also raises issues of consultation of nation members by decision-makers.

57 See, for example John Borrows, Freedom and Indigenous Constitutionalism (Toronto: University of Toronto Press, 2016), especially ch 1: "Physical Philosophy: Mobility and Indigenous Freedom"; Heidi Kiiwetinepinesiik Stark has also commented on mobility in Anishinaabeg understandings of territory: address at "Indigenous Resurgence and Reconciliation Symposium," a symposium on the 2012 Dalhousie University MacKay Lectures by Michael Asch, John Borrows and Jim Tully, 18-19 September 2015, Victoria, BC.

58 Étienne Rivard, “'Le Fond de l'Ouest': Territory, Oral Geographies, and the Métis in the Nineteenth-Century Northwest" in St-Onge, Podruchny \& Macdougall, supra note 6, 143. Nicole St-Onge, in her video on the BC Métis Mapping research website, states: "[T]he Metis had a mental map that was immense. They had no fear, if you track individuals, of going from Red River to Fort Chipewyan and beyond - Kelly Lake [BC], if you want - down to St Louis, down the Columbia. If you follow life histories, they went where the work was. And it's not ... I don't think in their minds they were leaving their home space. This was part of their world, their territory. I'm sure there were boundaries to it ... you 


\section{QUESTIONS INSPIRED BY A CREE RESEARCHER}

I once read the work of a Cree scholar whom I admire and who in many ways was a model for me. She stated she was an "appropriate researcher" to conduct research in a particular Cree nation, as she was a member of the nation, knew people, and could speak the language. She had a connection to the territory. While I understand and appreciate the importance of creating community connections, which is central to doing research with Indigenous people(s), ${ }^{59}$ and while I don't question that this scholar was an appropriate researcher, I am left asking how her statement might apply to me. What if I am a Metis researcher, who for many years had no community larger than my own family, and it was only through conducting my research that I discovered my connection to the community I was researching? What if I had known all my life the territory where I had conducted my research, and loved this territory like my true home, but only recently realized its Metis history? What if the people living in this territory have, like my family, connections to other territories? What if we have lost our languages? Am I then an appropriate researcher?

Through my dissertation research, I have deepened my connection with the territory where my Metis family settled, a territory I already knew and loved, but from which I had become increasingly disconnected over the years. My mother's family lived at Gleneden, in the Fly Hills just outside Salmon Arm, where their raw wood barn, outbuildings, and combination A-frame/shanty house sat perched just below a rocky, mountain outcropping and just above gently sloping fields of hay and alfalfa. I spent many happy visits at their place, often together with my aunts, uncles, and cousins - and cows, horses, cats, and dogs - enjoying a reprieve from city life in Vancouver. However, with the death in the 1990s of my aunt and uncle in nearby Eagle Bay and of my grandfather in Salmon Arm, my connections began to diminish. Then, just as I started to plan my field interviews, my grandmother died. A few years before, the family farm had been sold. The new owner subdivided the property, demolished the house and other buildings, and even changed the landscape, levelling the bench land on which the house and cabin had sat. The place I had always thought of as my "real" home was no more, and with the death of my grandmother, who by then had been living in town for some years, I wondered how I could continue to be connected to the Salmon Arm area. Unexpectedly, my community research allowed me to have new and positive connections and associations with this area, especially with Falkland - the "other side of the mountain" from Salmon Arm. Of course, these connections had actually always been there - I just hadn't realized it.

How could there be an invisible community? My grandmother told me that, at one time, people didn't parade around with Metis flags or sport sashes at the fall fair; however, they "were often aware of each other." In essence, she told me that for many years it was risky to identify as Metis. ${ }^{60}$ She also

didn't go beyond, maybe, south of St Louis, you didn't go north of Mackenzie, or whatever, but they travelled within their world and were comfortable." BC Métis Mapping <http://document.bcmetiscitizen.ca>.

59 Space does not permit a discussion here of the rich literature on Indigenous research ethics and methodologies, but on the importance of "creating community" in research, see, for instance, Linda Tuhiwai Smith, Decolonizing Methodologies: Research and Indigenous Peoples, 2nd ed (London: Zed, 2012); Shawn Wilson, Research Is Ceremony: Indigenous Research Methods (Halifax: Fernwood, 2008); Gregory Cajete, Native Science: Natural Laws of Interdependence (Santa Fe, NM: Clear Light, 2000).

60 The court in Powley acknowledges Metis communities can "go underground" without breaking continuity. Powley, supra note 3 at para 27. 
acknowledged that there might have been Metis families who never publicly revealed their identities. Later, she told me, this changed, and for years she had been seeing Metis cultural events advertised, although she had never chosen to attend.

One of my research participants lived in Eagle Bay, where my aunt and uncle had also lived. They had all known each other. Another research participant lived in Tappen, west of Salmon Arm, where my uncle and grandpa had worked at the mill. She had gone to school with another of my aunts. The wife of another participant from Westwold went to school in Salmon Arm with yet another uncle. My research path was the same path my own family had taken over the years. Along the Fur Brigade Trail, I visited my aunt and uncle in Kamloops and conducted an interview in Kamloops; on the road to interviewing people in Falkland, Vernon, Lumby and Oliver, I visited one cousin in Westwold, talked to another in Penticton; I visited my aunt and uncle in Osoyoos, and stayed with a Metis friend and her family in Keremeos. Again, the path of my family and friends was my research path - the path of Metis traders and packers.

\section{CROSSING THE MOUNTAINS}

Ptii Sourii sat in the cab of the truck as it rattled over the icy potholes of the Monashee Pass road. It was early December, and she and her family were moving to Salmon Arm. Her husband's arms and eyes were claimed by the road, his lips set in determination and concentration. Their smallest two children sat in front, while the three middle kids camped out in the truck bed, propped up on bedrolls and blankets, huddled together on a sandwich of mattresses that protected their winter food stores. A canvas tarp was stretched across a frame that was rigged to the sides of the truck, keeping everyone partially dry and only marginally warm. A little window of burlap at the back was all they could see of the road behind them.

Ptii Sourii thought, when they left Saskatchewan (sending their eldest son on the train with the dog and chickens), that their rig looked a little bit like the Red River carts that her Grandma Millie had told her about. With those carts, grandma said, you could get out and walk for a bit, you could get away from the insistent, loud squeaking of the wheels. You weren't stuck in such a small space all the time, as she was now, listening to the sounds of the tires on the snow, the laughter of her kids, and looking at the windshield that kept threatening to ice over, making her window on the world that much smaller.

Her gram had been born in Fort Garry and then her family left for Saskatchewan, stopping for a while in North Dakota. Her father, who called her "little mouse" because she was small but industrious, had been many places, but he had never been to BC. She thought of him and how long it might be until the next time she saw him.

She wondered what waited for her and her family across the divide. Her gram's uncle had gone there, had settled down, but that was long ago. She had heard stories of the mountains that loomed, blocking out the hugeness of the sky, the trees that were everywhere, inescapable. She had only gotten to know trees when they lived for a while in the Cypress Hills. Most of her life trees had been a novelty - and a delight. Where they'd lived before, west of Estevan, you could look as far as the eye could see and all you could see was prairie. She longed for trees, but mountains were another matter. Now they were huge, craggy, covered with snow. Would she grow to love them? Little Mouse covered her belly with her hand as her growing baby suddenly nudged her in the ribs. He would be born here. Did he know he was crossing the mountains? 
My Gram eventually grew to love the mountains, especially Mount Ida (in Secwepemctsín, Kela7scen, meaning "volcano"), which dominated the landscape, giving - she said - a protective feeling to the surrounding valley. From the top of the rocky outcropping above the house, which we often visited, even into her eighties, my grandmother would survey with fondness the panorama of the Salmon Arm valley, with Mount Ida to the right, Shuswap Lake to the left, and the valley and its creeks spread out at the feet of the Fly Hills. This was a favourite spot for a picnic, with the dogs, and sometimes even the cats in tow.

My grandparents and youngest uncle had defended their land from a forest fire in the early 1970s and saw most of their beloved hillside burned and neighbours evacuated. ${ }^{61}$ The fire came right down to the house. Because they disobeyed the evacuation order, my grandparents were able to save their house, barn, and outbuildings; those of their neighbours were mostly destroyed; many people lived in trailers for the next few years. I remember my grandmother's anger at the foresters' carelessness, as it was determined the fire was caused by the forestry workers not putting out their cigarettes. My grandmother experienced a similar anguish again in 1998, when fire burned most of the trees off of the Salmon Arm and Silver Creek sides of Mount Ida and over 7,000 people had to be evacuated. Again, this happened because of logging, logging on a mountain she told me the Secwepemc people believed was sacred.

She described her own sadness at these events as well as that of the Secwepemc and non-Aboriginal residents of Salmon Arm, but she also told me she thought the mountain was sad that people had treated it this way. ${ }^{62}$ This reflected similar thoughts she had expressed during the construction of a large hotel development on the Shuswap Lake waterfront downtown. She reminded me of a terrible flood that had occurred when I was a child and told me that one of the Shuswap Elders informed her then that there were cyclic floods on the lake - some of them high enough to flood the hotel. The flood of 2012, after my gram's death and during my first research trip, was significant, doing damage to the nearby lumber mill at Canoe, but the hotel was spared - that time.

In addition to the stories she told me of Salmon Arm and its surroundings, sometimes my grandmother talked to me about the prairie, describing the waving grasses, the alkali sloughs that ruined her moccasins, the cactus fruit savoured in summer. Even the Saskatchewan winters that produced layers of frost on wool blankets were recalled with joking fondness. Like my grandparents, my great-grandparents were farmers as well as hunters and trappers. My grandmother told me of the hard work of cutting and grinding pork scraps for headcheese and the consolation of eating deliciously crispy, dripping pork cracklings. She

61 Again, I am not trying to imply Metis have title in Shuswap or Okanagan territory, however much they might love it or identify with it. I am also not trying to imply that relationships with the land that have existed since time immemorial are the same as relationships Metis people might have with the same land. Rather than trying to resolve or completely delineate, I am gesturing towards those relationships that do exist, and am hoping to understand their significance.

62 Compare the sentiments of Secwepemc Elder Mary Thomas, as recorded by ethnobotanist Nancy J Turner: "Mary has always talked about the sacred mountain of her people, Kela 7scen (Mount Ida). For generations, Kela7scen provided the Secwepemc with a great variety of resources necessary to their physical and spiritual well-being. The people harvested and hunted plants and animals on the slopes of the mountain, they offered prayers to it and in return received guidance. Extensive logging on Kela7scen concerned Mary greatly, as did disputes taking place in the Salmon Arm community over resource use on the mountain, which she regarded as ominous." In Turner, The Earth's Blanket (Vancouver: Douglas and McIntyre, 2005) at 140. After seeing the destruction of the 1998 fire, which did not surprise her, "Mary sadly commented that this is what happens when people treat Nature, and each other, with disregard." In Turner, ibid. See also Michael D Blackstock's account of Mary Thomas' work in resolving resource disputes on Mount Ida: "Blue Ecology: A Cross-Cultural Approach to Reconciling Forest-Related Conflicts” (2005) 6:2 Perspectives: BC Journal of Ecosystems \& Management 38. 
described the elusiveness of the antelope, the many patient hours it took her father to stalk it, and his frustration - and wry delight - when it bolted too quickly out of the range of his rifle. Often, she told me about her nostalgia for the berry-picking parties and swimming holes of her youth, the fiddle music played by her brothers' band for weddings and dances. Her eyes would light up at the thought of wagon trips to town, but also of solitary walks punctuated by the cries of hawks and meadowlarks. These were the days of plenty before the Depression, before the prairie turned dry and dusty, before she raised seven children.

Many years later, after coming to know her new home in BC, my grandmother went back to Saskatchewan to visit her relatives. She told me she had been home but was glad to be home when she got back.

$* * *$

Of the fifty cases that have considered Powley so far, all but three of them have found against the Metis claimants. ${ }^{63}$ The three successful prairie cases $-R v$ Laviolette, ${ }^{64} R v$ Belhumeur, ${ }^{65}$ and $R v$ Goodon ${ }^{66}-$ have expanded the Powley definition of community to include greater acceptance of Metis mobility and interconnection with other Indigenous groups, as well as a recognition that Metis territories can be located in relatively large geographic regions. Even Willison acknowledges that a Metis community need not be located in a permanent settlement; it is enough if the community is "on the land." ${ }^{67}$ It remains to be seen whether this trend of expansiveness will continue; unfortunately, there have been no cases in line with these since $2008 .^{68}$ In Alberta, the court in $R v$ Hirsekorn ${ }^{69}$ established a test for mobility of Metis rights, which at least recognizes an important Metis reality, but Mr Hirsekorn lost because the court held there was no historic Metis community in southern Alberta, which was where he had been hunting. ${ }^{70}$

My scepticism about the usefulness of Powley is echoed by research participant and rights claimant Ron Nunn. Ron thinks Powley is problematic because it doesn't allow for mobility and Metis ideas of territory and partly because it takes an unreasonably narrow view of what is required to establish a Metis community. In discussing the $\mathrm{BC}$ cases, Ron says:

63 Not all the cases that consider Powley are about Metis rights, but more than half of them are.

$64 R$ v Laviolette, 2005 SKPC 70, [2005] 3 CNLR 202 (Sask Prov Ct) [Laviolette]. In this fishing case, a Metis community was found to exist in the Qu'Appelle Valley and environs, including the city of Regina.

$65 R v$ Belhumeur, 2007 SKPC 114 (Sask Prov Ct) [Belhumeur]. In this subsequent fishing case, the court recognized an historic Metis community in the area of northwest Saskatchewan bounded by Green Lake, Île a la Crosse, Lac la Biche, and Meadow Lake.

$66 \quad R v$ Goodon, 2008 MBPC 59 (Man Prov Ct) [Goodon]. In this hunting case, the court recognized an historic Metis community in a loosely defined area of southern Manitoba, including the city of Winnipeg south to the United States border and west to the Saskatchewan border.

67 Willison appeal, supra note 5 at para 24.

68 However, note that the appeal decision in the Alberta case $R v$ Kelley, 2006 ABPC 17, 2007 ABQB 41, says that arbitrarily limiting the "site" of site-specific rights is not correct and that in looking at site specificity, the courts should consider the historical context. However, a site-specific right was not found on the facts.

$69 \quad R v$ Hirsekorn, [2010] AJ No 1389, aff'd in part [2011] AJ No 1217, aff'd [2013] ABCA 242.

70 For a critique of the new "traditional territory test" in this case from a Metis legal perspective, see Karen Drake, " $R v$ Hirsekorn: Are Métis Rights a Constitutional Myth?” (2013) 92:1 Can Bar Rev 149. 
I think [the judges were] looking again for that whitewashed house, little picket fences, and rosebushes by the door, that prove without a doubt that a Metis lived here, either in the south Okanagan or in Fort Kamloops, or anywhere else. That's what they decided they wanted to see ... ${ }^{71}$

I hope that the stories I have told reflect that Metis concepts of territory and community are not the concepts of Powley, which reflect assumptions based in English property law and English social and settlement patterns. ${ }^{72}$ As Metis people, we have ties among our own communities and with other Indigenous and non-Indigenous communities. ${ }^{73} \mathrm{We}$ have local as well as geographically far-reaching connections. Metis territory is similarly complex and may be better represented by expansive, overlapping network regions than by sections and townships. ${ }^{74}$ Contrary to some detractors' views, however, Metis communities and lands have not become so vaguely defined as to be non-existent. There are still many "historic" territories and communities that we and our neighbours recognize, even if they are not recognized by the courts of Canada.

While my family's wanderings across Canada and into the United States reflect a typical peripatetic Metis pattern, the existence of these territorial and community webs begs the question - where would I have provable Metis rights? I have ancestral Metis connections to many places as well as ancestral nonMetis connections to many places. I have non-ancestral (work, social) connections to many places, including places where some of my Metis ancestors lived. What if I had been caught fishing without a licence at the mouth of the Capilano River, as I almost was long before my law journey ever began? While I grew up in Coquitlam and lived in Vancouver for many years, I don't have an ancestral connection to the Lower Mainland that I know of. If I had been, say, hunting in the environs of Falkland, I might have fared similarly to Greg Willison or perhaps slightly better, as I am related to Metis people who travelled along the Brigade Trails and lived at the trading posts in BC in the early 1800s, and who settled in the Okanagan Valley and environs in the mid-1800s and actually stayed. However, what if I had been hunting in Falkland but lived in Victoria (a likely scenario)? Even if there were found to be a historic Metis community in Falkland, and I had an ancestral connection to it - and even if there were found to be continuity with the present-day community, there would still be a disconnect.

My and my family's wanderings have convinced me that it would be very difficult for me to evade the community conundrum under any configuration, despite having documented Red River ancestry and an ancestral connection to many traditional Metis territories, including in British Columbia; despite Metis

71 Interview with Ron Nunn, 4 August 2012, Oliver, BC.

72 See Teillet, supra note 21 at 1-37.

73 This is recognized, for instance, in Laviolette, Belhumeur and Goodon as well as in Paul, supra note 36, and in Cunningham v Alberta, [2011] 2 SCR 670, which examine the connections between Metis and First Nations people, and the potential for Metis people to have both Metis and First Nations identities.

74 Teillet, supra note 21 at 1-30-1-39. This is not to deny that there are distinct Metis territories, which may have been conceived of in similar ways as First Nations or Inuit traditional territories or that many of the lands held by the Metis at Red River were held based on the French seigneurial system. Metis lots on Red River were later acknowledged by the imported English law as being held in fee simple. Unfortunately, the French derivation of this form of land holding was the reason the Supreme Court of Canada in Manitoba Métis Federation, supra note 36, held that a fiduciary duty had not arisen with respect to Metis lands in Red River; because Metis people had adapted European-derived land use laws to suit themselves, this was not seen as sufficiently Indigenous. 
self-identification and community acceptance; and despite living in a community (Victoria) and being associated with a community (Thompson/Okanagan) that could - in my view - meet the Powley criteria as being "historic." My questions about my own situation lead to the wider question affecting all Metis people in Canada: given the strictures of the Powley case, can the courts contend with the complexities of Metis histories, communities, and territories? ${ }^{75}$ I am not sure if the answer can ever be "yes," but it will always be "no" if the courts continue to ignore Metis legal perspectives.

75 In light of Powley, many research participants were more comfortable with the possibility of negotiating, rather than litigating, Metis rights. The negotiation process with British Columbia was stalled for many years, but following the $R v$ Daniels decision at the Federal Court of Appeal, BC reopened negotiations with the Métis Nation of British Columbia, the largest Metis political organization in the province. The Federal Court of Appeal ruling that the federal government has jurisdiction concerning Metis peoples and lands has been upheld by the Supreme Court of Canada: Daniels v Canada, [2013] FCR 6, aff'd 2016 SCC 12. It is not clear how this case will affect other Metis-provincial relationships, although the recent memorandum of understanding between Manitoba and the Manitoba Métis Federation is perhaps a first step towards contending with the crown's breach of Metis land rights in that province. Note that some research participants saw "rights" (or "use rights") as not properly describing Metis harvesting practices, which have physical, mental, emotional, and spiritual aspects. The words "harvesting" and "wildlife management" were similarly critiqued. Interview with Elder Lottie McDougall Kozak 15 June 2012, Falkland, BC; interview with Dan LaFrance, 7 May 2013, Whitley Lake, BC. 